\title{
PERBEDAAN PENGARUH MEDIA PEMBELAJARAN LAGU DAN SLIDE PADA PRAKTIK MENCUCI TANGAN DITINJAU DARI JENIS KELAMIN
}

\author{
Hanifa Andisetyana Putri \\ Universitas 'Aisyiyah Yogyakarta \\ Email: hanifaaputri.90@gmail.com
}

\begin{abstract}
Abstrak
Penelitian ini bertujuan untuk menganalisis perbedaan pengaruh media pembelajaran lagu dan slide terhadap praktik mencuci tangan ditinjau dari jenis kelamin. Jenis penelitian menggunakan quasi experimental design. Teknik sampling yang digunakan adalah purposive sampling dengan jumlah sampel 74 siswa TK Negeri Pembina Sragen. Instrumen yang digunakan adalah checklist mencuci tangan. Teknik analisis data menggunakan two way anova. Hasil: 1) Ada perbedaan pengaruh media pembelajaran lagu dan slide terhadap praktik mencuci tangan, dengan nilai $p=0,005 ; 2$ ) Ada perbedaan pengaruh kelamin laki-laki dan perempuan terhadap praktik mencuci tangan, dengan nilai $\mathrm{p}=0,000$; 3) Tidak ada interaksi antara media pembelajaran terhadap praktik mencuci tangan ditinjau dari jenis kelamin, dengan nilai $p=0,377$. Kesimpulan: Tidak ada interaksi antara media pembelajaran lagu dan slide terhadap praktik mencuci tangan ditinjau dari jenis kelamin.
\end{abstract}

Kata kunci: media lagu, slide, kelamin, praktik mencuci tangan

\section{THE DIFFERENCES OF INFLUENCE MEDIA LEARNING SONG AND SLIDES ON HAND WASHING PRACTICES BASED ON GENDER}

\begin{abstract}
Absract
The study aims to analyse the differences used of songs and slides in practicing hand washing in terms of gender. The research used a quasi-experimental design. Sampling technique used in the study is purposive sampling with a sample of 74 kindergarten students Negeri Pembina Sragen. The instrument used a checklist of washing hands. Data were analyzed using two way ANOVA. The results are:1) There is a difference of using songs and slides in practicing of hand washing, with the value of $p=0.005 ; 2$ ) There is a difference in male and female practice of hand washing, with a value of $p=0.000 ; 3$ ) There is no difference between the use of song and slides in practicing of hand washing in male and female students, with a value of $p=0.377$. There is no difference between the used of song and slides in practicing of hand washing in terms of gender.
\end{abstract}

Keywords: media song, slides, gender, hand washing practices

\section{PENDAHULUAN}

Semua orang memiliki idaman menjadi orang yang sehat. Berdasarkan Undang-undang Nomor 36 Tahun 2009 tentang kesehatan, menjelaskan bahwa kesehatan adalah keadaaan sehat, baik secara fisik, mental, spiritual maupun sosial yang memungkinkan setiap orang untuk hidup produktif secara sosial dan ekonomis. Sehat bukan merupakan tujuan hidup, namun alat untuk mencapai suatu kehidupan yang produktif (Machfoedz dan Suryani, 2008:89).

Salah satu upaya untuk mencapai kondisi yang sehat dilakukan dengan cara mengubah perilaku dan menciptakan lingkungan yang sehat. Perilaku Hidup Bersih dan Sehat (PHBS) merupakan sekumpulan perilaku yang dilakukan atas dasar kesadaran seseorang untuk 
menolong dirinya sendiri di bidang kesehatan dan berperan aktif dalam meningkatkan derajat kesehatan. PHBS merupakan salah satu strategi untuk menghasilkan kemandirian seseorang di bidang kesehatan. Kebersihan perseorangan (personal hygiene) merupakan implementasi dari PHBS yang menunjukkan usaha kesehatan yang dilakukan seseorang untuk menjaga kebersihan diri, salah satunya adalah kebersihan tangan (Siswanto, 2010:55).

Mencuci tangan adalah tindakan yang dilakukan untuk mewujudkan pelaksanaan program PHBS dalam menjaga kebersihan tangan. Mencuci tangan merupakan hal yang sederhana, namun banyak orang malas melakukannya. Berdasarkan hasil studi Environmental Health Risk Assessment yang dilakukan di 55 kabupaten/kota di 16 provinsi di Indonesia pada tahun 2013 menunjukkan bahwa baru $18,5 \%$ masyarakat melakukan kebiasaan mencuci tangan pakai sabun. Hal ini terjadi karena keyakinan bahwa apabila tidak ada kotoran yang terlihat menempel, maka tidak perlu mencuci tangan. Tangan yang terlihat bersih tidak menjamin bahwa tangan tersebut bebas dari kuman. Sumber penyebaran kuman dapat berasal dari benda-benda yang sering dipegang oleh seseorang, sehingga membuktikan bahwa tangan dapat menyebarkan penyakit dari aktivitas bersentuhan dengan berbagai benda. Mencuci tangan cukup efektif untuk mencegah kontak dengan kumankuman tersebut (Depkes RI, 2013).

Data dari UNICEF menyebutkan bahwa perubahan perilaku sederhana dengan adanya kebiasaan mencuci tangan pakai sabun dapat menurunkan risiko diare hingga $50 \%$ dan ISPA hingga $45 \%$, sehingga dibutuhkan adanya suatu gerakan untuk mensosialisasikan program mencuci tangan. Hari Cuci Tangan Pakai Sabun Sedunia (HCTPS) yang diperingati setiap tanggal 15 Oktober merupakan kampanye global yang dicanangkan oleh PBB untuk mewujudkan perilaku hidup bersih dan sehat melalui mencuci tangan (Prawira, 2013).

Setiap hari ada lebih dari 5.000 anak penderita diare meninggal dunia di seluruh dunia akibat kurangnya akses air bersih, fasilitas sanitasi, dan pendidikan kesehatan. Hal ini menunjukkan bahwa pendidikan kesehatan merupakan bagian yang integral dari upaya kesehatan masyarakat. Menurut Siswanto (2010) pendidikan kesehatan perlu diberikan sedini mungkin, seperti pada usia kanakkanak. Pendidikan kesehatan pada anak usia dini dapat menumbuhkan kesadaran dan membentuk perilaku hidup bersih dan sehat sedini mungkin, seperti kebiasaan mencuci tangan yang dapat meningkatkan derajat kesehatan seseorang. Anak-anak merupakan golongan usia yang paling rentan terhadap penyakit akibat perilaku yang tidak sehat dan sanitasi yang buruk. Maka dari itu anak usia dini menjadi sasaran strategis dari upaya kesehatan masyarakat.

Hasil studi pendahuluan dilakukan di Taman Kanak-kanak (TK) Negeri Pembina yang merupakan salah satu TK favorit di Kabupaten Sragen, penulis menemukan fakta bahwa siswa di sekolah tersebut belum pernah mendapatkan pendidikan kesehatan tentang mencuci tangan dengan benar. Padahal pendidikan kesehatan menjadi tanggung jawab semua pihak dari keluarga, instansi pendidikan, pemerintah, dan masyarakat. Orang tua menitipkan putra dan putrinya di suatu instansi pendidikan untuk memperoleh pengetahuan dan diajarkan nilai-nilai penting dalam kehidupan termasuk tentang kebersihan. Sekolah mengajarkan siswa tentang berbagai hal melalui media pembelajaran yang menarik dan sesuai dengan usia siswa.

Perkembangan individu menurut Morisson (Yus, 2011:86) siswa TK berada pada usia 4-6 tahun pada kelompok preschool and kindergarten. Pada usia ini anak menyukai kegiatan belajar yang bersifat menyenangkan untuk pengembangan kreativitasnya. Proses 
belajar yang menyenangkan seperti dengan bermain, gambar, bernyanyi memberikan kesan pada anak sehingga lebih mudah dalam menyerap pengetahuan yang disampaikan guru. Menurut Gardner pada usia 5-6 tahun, anak memiliki perkembangan dimensi kecerdasan interpersonal yaitu menunjukkan minat untuk mengetahui tentang perbedaan jenis kelamin. Hal ini menjadi dasar dalam pengelolaan pembelajaran apakah terdapat perbedaan antara anak laki-laki dan perempuan dalam menyerap dan menerapkan pelajaran yang diberikan oleh guru (Rachmawati dan Kurniati, 2010:34).

Berdasarkan latar belakang tersebut maka penulis menyimpulkan perlu adanya tindakan untuk meningkatkan derajat kesehatan siswa TK dengan pembiasaan PHBS mencuci tangan melalui pendidikan kesehatan. Selain itu dalam rangka memudahkan siswa dalam menyerap informasi kesehatan yang diberikan, maka digunakan media pembelajaran yang tepat.

Mengacu pada permasalahan yang telah dijabarkan sebelumnya maka muncul beberapa pertanyaan penelitian sebagai berikut:

1. Apakah ada perbedaan pengaruh media pembelajaran lagu dan slide terhadap praktik mencuci tangan?

2. Apakah ada perbedaan pengaruh jenis kelamin laki-laki dan perempuan terhadap praktik mencuci tangan?

3. Apakah ada interaksi pengaruh antara media pembelajaran lagu dan slide terhadap praktik mencuci tangan ditinjau dari jenis kelamin?

Tujuan penelitian ini adalah untuk menganalisis perbedaan pengaruh media pembelajaran lagu dan slide terhadap praktik mencuci tangan ditinjau dari jenis kelamin.

Pendidikan kesehatan merupakan bagian dari program kesehatan yang memiliki peran penting dalam proses perubahan perilaku dari berbagai pengalaman belajar yang mendorong seseorang, kelompok, maupun masyarakat mencapai hidup sehat. Pendidikan kesehatan disampaikan menggunakan media pembelajaran yang mengantarkan pesan antara pemberi pesan (guru) kepada penerima pesan (siswa) (Anitah, 2008:64).

Penelitian ini menggunakan media lagu dan slide. Lagu adalah salah satu media audio yang menstimulasi indera pendengaran dalam proses pembelajaran. Media ini mengajarkan siswa untuk bernyanyi menggunakan syair-syair yang sesuai dengan materi yang diajarkan. Sedangkan media slide adalah media visual yang diproyeksikan. Slide adalah suatu materi yang bersifat individual (ditampilkan satu per satu) dapat berupa gambar maupun tulisan, diatur dengan jumlah yang direncanakan, dan disajikan melalui proyektor (LCD) (Anitah, 2008:76).

Materi yang disampaikan dalam pendidikan kesehatan adalah tentang mencuci tangan. Siswa diharapkan dapat melakukan praktik mencuci tangan dengan benar sesuai dengan 7 langkah hygiene mencuci tangan (Depkes RI, 2008:43). Kemudian penelitian ini meninjau praktik mencuci tangan siswa berdasarkan jenis kelamin antara siswa laki-laki dan perempuan.

Hipotesis dalam penelitian ini antara lain ada perbedaan pengaruh media pembelajaran lagu dan slide terhadap praktik mencuci tangan, ada perbedaan pengaruh kelamin laki-laki dan perempuan terhadap praktik mencuci tangan, serta ada interaksi pengaruh antara media pembelajaran lagu dan slide terhadap praktik mencuci tangan ditinjau dari kelamin

\section{METODE}

Lokasi penelitian ini adalah di TK Negeri Pembina Sragen yang terletak di Jalan Kenanga No.2 Beloran, Sragen Kulon, Sragen. Penelitian dilaksanakan mulai bulan Desember 2013 sampai dengan Mei 2014. 
Jenis penelitian menggunakan quasi experimental design yang melibatkan dua variabel bebas (media dan kelamin) serta satu variabel terikat (praktik mencuci tangan) dengan menggunakan rancangan faktorial $2 \times 2$.

Teknik sampling yang digunakan adalah purposive sampling, dimana sampel ditentukan dengan pertimbangan tertentu yaitu siswa TK dalam rentang usia 5-6 tahun. Jumlah sampel dalam penelitian ini berjumlah 74 siswa yang terdiri dari siswa laki-laki sebanyak 32 anak dan siswa perempuan sebanyak 42 anak yang dibagi menjadi dua kelompok yaitu eksperimen dan kontrol yang masing-masing berjumlah 37 anak.

Teknik pengumpulan data yang digunakan dalam penelitian ini adalah observasi. Peneliti melakukan pengamatan langsung dan memberikan penilaian terhadap praktik mencuci tangan pada siswa TK Negeri Pembina menggunakan instrumen checklist. Checklist mencuci tangan dibuat berdasarkan teori-teori pada Pelatihan Klinik Asuhan Persalinan Normal (APN) yang dikeluarkan oleh Departemen Kesehatan RI tahun 2008.

Teknik analisis data yang dilakukan antara lain tes kesetaraan dengan uji independent t-test untuk mengetahui apakah siswa dari dua kelompok (eksperimen dan kontrol) memiliki kemampuan yang setara dari skor pretest. Kemudian setelah diberikan perlakuan dan diperoleh skor posttest, maka dilakukan pengujian hipotesis dengan membandingkan rata-rata kelas eksperimen dan kontrol menggunakan uji Two Way Anova dengan taraf signifikansi (a) 5\%. Dimana syarat dilakukan pengujian dengan ANOVA adalah data memiliki varians yang sama dan distribusi data harus normal dengan uji ShapiroWilk (jumlah sampel pada tiap kategori $<50)$.

\section{HASIL DAN PEMBAHASAN}

Hasil uji kesetaraan yang dilakukan pada skor pretest praktik mencuci tangan pada kedua kelompok dan menggunakan uji independent t-test diperoleh hasil sebagai berikut:

Tabel 1. Hasil uji kesetaraan skor pretest

\begin{tabular}{llrr}
\hline & & $\begin{array}{c}\text { Levene's Test } \\
\text { for Equality } \\
\text { of Variances } \\
\text { Sig. }\end{array}$ & $\begin{array}{c}\text { t-test for } \\
\text { Equality } \\
\text { of Means } \\
\text { Sig. } \\
\text { (2-tailed) }\end{array}$ \\
\hline & $\begin{array}{l}\text { Equal } \\
\text { variances }\end{array}$ & .364 & .423 \\
Praktik & assumed & & \\
Cuci & $\begin{array}{l}\text { Equal } \\
\text { Tangan } \\
\text { variances } \\
\text { not }\end{array}$ & & .423 \\
& assumed & & \\
\hline Sumber: & & \\
\hline
\end{tabular}

Sumber: Hasil Olah Data SPSS 19.0

Pada tabel 1 diperoleh hasil pada levene test memiliki probabilitas 0,364 dimana probabilitas $>0,05$ menunjukkan varians populasi yang sama. Maka dari itu uji t-test menggunakan asumsi equal variances assumed diperoleh probabilitas 0,423 . Probabilitas $>0,05$ menunjukkan bahwa kedua kelompok memiliki kemampuan rata-rata awal yang sama.

Uji kesetaraan skor posttest menggunakan Levene Test diperoleh hasil bahwa nilai probabilitas Levene Test $>0,05$ yaitu 0,194 dimana sampel memiliki varians populasi yang sama.

Syarat yang harus dipenuhi selanjutnya untuk pengujian menggunakan ANOVA adalah sampel berasal dari populasi yang terdistribusi normal atau tidak. Di bawah ini merupakan hasil uji normalitas menggunakan Shapiro-Wilk.

Berdasarkan hasil pada Tabel 2 menunjukkan bahwa seluruh data pada tiap kategori memiliki nilai kemaknaan (p) $>0,05$ sehingga data terdistribusi normal.

Langkah selanjutnya adalah melakukan pengujian hipotesis. Penelitian ini menggunakan uji analisis variansi dua jalan (Two Way Anova) dengan frekuensi sel yang tidak sama. 
Tabel 2. Hasil uji normalitas posttest

\begin{tabular}{lrcc}
\hline & \multicolumn{3}{c}{ Shapiro-Wilk } \\
& Statistic & df & \multicolumn{1}{c}{ Sig. } \\
\hline $\begin{array}{l}\text { PosttestLagu Laki- } \\
\text { laki }\end{array}$ & .962 & 15 & .731 \\
$\begin{array}{l}\text { PosttestLagu } \\
\begin{array}{l}\text { Perempuan } \\
\text { PosttestSlideLaki- }\end{array}\end{array}$ & .915 & 22 & .059 \\
$\begin{array}{l}\text { laki } \\
\text { PosstestSlide }\end{array}$ & .918 & 17 & .136 \\
Perempuan & .946 & 20 & .312 \\
\hline
\end{tabular}

Sumber: Hasil Olah Data SPSS 19.0

Distribusi rerata pada masingmasing sel yang berupa rerata skor praktik mencuci tangan dengan variasi media dan kelamin disajikan dalam tabel berikut ini:

Tabel 3. Distribusi rerata skor praktik mencuci tangan

\begin{tabular}{lccc}
\hline \multirow{2}{*}{ Kelamin } & $\begin{array}{c}\text { Lagu } \\
\text { (A1) }\end{array}$ & $\begin{array}{c}\text { Slid } \\
\text { e } \\
\text { (A2) }\end{array}$ & $\begin{array}{c}\text { Rerat } \\
\text { a }\end{array}$ \\
\hline Laki-laki (B1) & 8,93 & 7,47 & 8,16 \\
Perempuan (B2) & 10,2 & 9,45 & 9,86 \\
& 3 & & \\
Rerata & 9,70 & 8,54 & 9,12
\end{tabular}

Sumber: Hasil Olah Data SPSS 19.0

Berdasarkan tabel 3 dapat dilihat bahwa skor praktik mencuci tangan dengan media lagu memiliki rerata yang lebih tinggi daripada media slide.

Selain itu siswa perempuan memiliki rerata yang lebih tinggi dibandingkan dengan siswa laki-laki. Setelah dilakukan analisis Two Way Anova maka berdasarkan tabel 4 diperoleh hasil sebagai berikut.

Tabel 4. Hasil analisis Two Way Anova

\begin{tabular}{lrr}
\hline Source & \multicolumn{1}{c}{ F } & \multicolumn{1}{c}{ Sig. } \\
\hline Corrected & 9.424 & .000 \\
Model & & \\
Intercept & 2194.115 & .000 \\
Media & 8.457 & .005 \\
Kelamin & 18.059 & .000 \\
Media * & .792 & .377 \\
Kelamin & & \\
\hline
\end{tabular}

Sumber: Hasil Olah Data SPSS 19.0
1. Pada kolom media diperoleh $F$ hitung $=8,457$ dan $F$ tabel $=3,97$ dengan probabilitas 0,005 . Ho ditolak dan Ha diterima apabila $\mathrm{F}$ hitung $>\mathrm{F}$ tabel dan probabilitas $<0,05$, sehingga hipotesis pertama terbukti bahwa ada perbedaan pengaruh media pembelajaran lagu dan slide terhadap praktik mencuci tangan. Lagu lebih efektif digunakan sebagai media untuk mengajarkan cuci tangan yang benar pada siswa TK. Media slide hanya menampilkan materi berupa slide power point yang dilengkapi gambar dan tulisan, kemudian siswa diharapkan memperhatikan seluruh tampilan slide yang disajikan. Siswa cenderung pasif dan merasa bosan karena mereka harus mendengarkan sambil berusaha menghafalkan urutan materi tentang mencuci tangan dari awal hingga akhir. Media ini kurang memberikan daya tarik karena proses belajar terkesan formal dan sistematis. Sedangkan lagu atau bernyanyi merupakan media yang sangat terjangkau karena dapat dilakukan tanpa menggunakan alat khusus, serta dapat digunakan kapan dan di mana saja. Bernyanyi dapat mengaktifkan kedua bagian otak manusia secara bersamaan. Otak bagian kanan menentukan kecerdasan emosi, kreativitas, dan cita rasa estetis, sedangkan otak bagian kiri membantu manusia untuk berpikir, berhitung, menganalisa, dan merinci sesuatu. Selain itu lagu dapat mengasah daya ingat seseorang, menciptakan suasana yang menyenangkan, menghilangkan ketegangan, dan membuat pikiran selalu siap untuk mampu berkonsentrasi (Wangsa, 2013:87). Seperti pada penelitian yang pernah dilakukan oleh Rachmawati (2013:7) tentang penggunaan media panggung boneka dalam pendidikan personal hygiene cuci tangan menggunakan sabun di air mengalir pada siswa 
sekolah dasar (SD), diperoleh hasil bahwa ada perbedaan pengetahuan dan ketrampilan sebelum dan sesudah menggunakan media panggung boneka namun dinilai kurang efektif. Hal ini disebabkan karena karakteristik siswa yang berbeda antara dua kelompok perlakuan serta tampilan panggung boneka yang masih tradisional sehingga kurang menarik bagi siswa. Maka dari itu diperlukan media yang tepat dan menarik bagi siswa sehingga pesan pendidikan kesehatan yang disampaikan dapat terserap dengan maksimal, salah satunya dengan lagu.

2. Pada kolom kelamin diperoleh $\mathrm{F}$ hitung $=18,059$ dan $F$ tabel $=3,97$ dengan probabilitas 0,000 . Ho ditolak dan Ha diterima apabila $\mathrm{F}$ hitung $>\mathrm{F}$ tabel dan probabilitas $<0,05$, sehingga hipotesis kedua terbukti bahwa ada perbedaan pengaruh kelamin laki-laki dan perempuan terhadap praktik mencuci tangan. Perempuan lebih mudah menyerap materi yang disampaikan dan menerapkan praktik mencuci tangan dengan benar dibandingkan laki-laki. Perempuan memiliki kemampuan penginderaan yang lebih peka daripada laki-laki. Jangkauan penglihatan perempuan lebih lebar dan dapat melihat sesuatu secara lebih rinci. Selain itu perempuan juga memiliki kemampuan mengendalikan bicara dan pendengaran yang dapat aktif secara bersamaan. Hal ini terjadi karena mereka dapat mendengar dan berkomunikasi jauh lebih baik daripada laki-laki (Allan dan Pease, 2012:98). Laki-laki memiliki penglihatan yang lebih terfokus daripada perempuan. Mereka dapat melihat dengan jelas, tepat, dan lebih jauh pada benda-benda yang tepat berada di depannya. Di sisi lain lakilaki memiliki kemampuan mendengar yang kurang efektif, sehingga ia tidak dapat berbicara dan mendengarkan sesuatu dalam waktu yang bersamaan (Gray, 2013:65). Anak perempuan dapat mendengarkan penjelasan dengan lebih baik dan rinci daripada anak laki-laki. Perempuan dapat menghafal syair lagu dengan lebih cepat karena dapat mengendalikan indera pendengarannya sambil bernyanyi secara bersamaan. Selain itu perempuan juga dapat mengolah informasi lisan maupun visual yang disajikan melalui slide karena mereka dapat fokus melakukan beberapa pekerjaan dalam waktu yang bersamaan dan mempraktikkan cara mencuci tangan yang benar sesuai dengan materi yang mereka terima. Berbeda dengan perempuan, sebetulnya laki-laki juga memiliki kemampuan untuk mendengar dan berkomunikasi dengan baik, namun tidak dapat dilakukan dalam waktu yang bersamaan. Mereka membutuhkan waktu untuk fokus dalam satu pekerjaan dahulu kemudian beralih ke pekerjaan lain secara bergantian. Laki-laki juga dapat menghafal syair lagu, memahami materi yang disajikan melalui slide, serta menerapkan praktik mencuci tangan dengan benar namun membutuhkan konsentrasi untuk lebih fokus dan waktu yang lebih lama daripada perempuan.

3. Pada kolom media*kelamin diperoleh $\mathrm{F}$ hitung $=0,792$ dan $\mathrm{F}$ tabel $=3,97$ dengan probabilitas 0,377 . Ho ditolak dan Ha diterima apabila $\mathrm{F}$ hitung $>\mathrm{F}$ tabel dan probabilitas $<0,05$. Maka dari itu hipotesis ketiga tidak terbukti dan diperoleh hasil bahwa tidak ada interaksi antara media pembelajaran lagu dan slide terhadap praktik mencuci tangan ditinjau dari jenis kelamin karena $\mathrm{F}$ hitung $<\mathrm{F}$ tabel dan probabilitas $>0,05$. Media dan kelamin masing-masing terbukti memiliki pengaruh terhadap praktik mencuci tangan. Namun keduanya tidak memiliki interaksi secara 
bersama-sama terhadap praktik mencuci tangan. Jenis kelamin lakilaki maupun perempuan ternyata tidak menentukan jenis media pembelajaran yang lebih disenangi dalam penyampaian materi mencuci tangan. Pemilihan media yang tepat dilakukan untuk memberikan kesan positif terhadap aktivitas belajar yang dilalui siswa. Hal ini ternyata sangat dipengaruhi oleh kecenderungan gaya dan tipe belajar masing-masing siswa dan tidak berdasarkan perbedaan kelamin (Ula, 2013:25). Tiap siswa memiliki tipe belajar yang berbeda. Cara seseorang untuk menyerap, mengolah informasi, dan memanifestasikan dalam wujud perilaku sangat mempengaruhi hasil belajar yang diperoleh. Maka dari itu, guru dituntut untuk merancang dan memberikan proses belajar yang inovatif, bermakna, dan beragam memenuhi kebutuhan siswa yang heterogen, salah satunya melalui pemilihan media pembelajaran. Media lagu merupakan media yang tepat diberikan pada siswa dengan tipe auditorik baik laki-laki maupun perempuan. Siswa dengan tipe auditorik lebih mudah mencerna, mengolah, dan menyampaikan informasi dengan cara mendengarkan secara langsung. Selain itu mereka belajar dengan mendengarkan dan mengingat apa yang disampaikan daripada apa yang dilihat. Sedangkan media slide lebih tepat diberikan pada siswa dengan tipe visual baik laki-laki maupun perempuan. Mereka lebih suka membaca dan lebih mudah mengingat apa yang dilihat daripada apa yang didengar (Ula, 2013:13).

Berdasarkan hal tersebut maka seorang guru dapat menggunakan lebih dari satu media pembelajaran untuk melayani keberagaman karakter dan tipe belajar siswa. Pemberian pendidikan kesehatan tentang mencuci tangan juga dapat disampaikan melalui kombinasi antara media slide kemudian dapat dinyanyikan bersama. Hal ini dapat meningkatkan minat siswa untuk melakukan praktik mencuci tangan karena mereka dapat menyerap materi dengan cara yang sesuai dengan tipe belajar mereka.

\section{PENUTUP}

Berdasarkan penjelasan di atas, maka diperoleh beberapa simpulan antara lain ada perbedaan pengaruh media pembelajaran lagu dan slide terhadap praktik mencuci tangan dimana media lagu lebih efektif daripada slide, ada perbedaan pengaruh jenis kelamin lakilaki dan perempuan terhadap praktik mencuci tangan dimana perempuan lebih cepat dan mudah menyerap materi pendidikan kesehatan dan mempraktikkan cara mencuci tangan yang benar daripada laki-laki, dan tidak ada interaksi antara media pembelajaran lagu dan slide terhadap praktik mencuci tangan ditinjau dari jenis kelamin dimana pemilihan metode pembelajaran tidak dipengaruhi secara langsung oleh jenis kelamin.

Beberapa saran dari penelitian ini adalah tiap sekolah diharapkan dapat menyediakan dan meningkatkan fasilitas kebersihan bagi siswa seperti air bersih, tempat cuci tangan, sabun untuk mendukung kebiasaan pola hidup bersih dan sehat (PHBS). Selain itu guru diharapkan dapat mengembangkan kreativitas dalam menggunakan kombinasi media pembelajaran yang sesuai dengan karakteristik siswa untuk meningkatkan motivasi siswa dalam belajar tentang hidup bersih dan sehat. Kemudian bagi para siswa pada khususnya dan masyarakat pada umumnya diharapkan menyadari pentingnya mencuci tangan dan melakukannya sebagai suatu kebiasaan yang harus selalu diterapkan untuk menjaga kebersihan diri. 
DAFTAR PUSTAKA

Allan dan Pease, B. 2012. Why Men Don't Listen and Women Can't Read Maps. Jakarta: Ufuk Press.

Anitah, S. 2008. Media Pembelajaran. Surakarta: UNS Press.

Depkes RI. 2008. Pelatihan Klinik Asuhan Persalinan Normal: Asuhan Esensial, Pencegahan dan Penanggulangan Segera Komplikasi Persalinan dan Bayi Baru Lahir. Jakarta: Bakti Husada.

Depkes RI, 2013. HCTPS 2013: Tanganku Bersih Hidupku Sehat. www.depkes.go.id. Diakses pada tanggal 20 Desember 2013 pukul 05.30 WIB.

Gray, J. 2013. Men Are From Mars, Women Are From Venus. Jakarta: Gramedia.

Machfoedz, I dan Suryani, E. 2008. Pendidikan Kesehatan Bagian dari Promosi Kesehatan. Yogyakarta: Fitramaya.

Prawira, A.E. 2013. Sejak Dini, Sebaiknya Anak Sudah Diajari Cuci Tangan Pakai Sabun. www.liputan6.com. Diakses pada tanggal 20 Desember 2013 pukul 05.40 WIB.

Rachmawati, R.D. 2013. Penggunaan Media Panggung Boneka dalam
Pendidikan Personal Hygiene Cuci Tangan Menggunakan Sabun di Air Mengalir. Jurnal Promosi Kesehatan. Vol 1. No.1. Halaman 19.

Rachmawati, Y dan Kurniati, E. 2010. Strategi Pengembangan Kreativitas pada Anak Usia Taman KanakKanak. Jakarta: Kencana Prenada Media Group.

Siswanto, H. 2010. Pendidikan Kesehatan Anak Usia Dini. Yogyakarta: Pustaka Rihama.

Ula, S.S. 2013. Revolusi Belajar: Optimalisasi Kecerdasan melalui Pembelajaran Berbasis Kecerdasan Majemuk. Yogyakarta: Ar-Ruzz Media.

Undang-undang Nomor 36 Tahun 2009. www.jkn.kemkes.go.id. Diakses pada tanggal 24 Desember 2013 pukul 05.40 WIB.

Wangsa, T.H.W. 2013. Mukjizat Musik: Terapi Jitu Kecerdasan Anak Melalui Musik. Yogyakarta: Lintang Aksara.

Yus, A. 2011. Penilaian Perkembangan Belajar Anak Taman Kanak-Kanak. Jakarta: Kencana Prenada Media Group. 